\title{
Effects of Radish and Turnip Intercropping with Faba Bean on Growth and Yield for these Crops under Assiut conditions
}

\author{
S.Y. Atallah and H. S. Abbas \\ Department of Vegetable Crops, Faculty of Agriculture, Assiut University Assiut, Egypt
}

Received on: 5 /1/2017

Accepted for publication on: $30 / 1 / 2017$

\begin{abstract}
The current study evaluates the efficiencies of faba bean, turnip and radish grown as sole crops and when radish and turnip intercropped with faba bean on growth, yield and quality characteristics. A field experiment was carried out during 2014- 2015 and 2015-2016 seasons at the Experimental Farm of Faculty of Agriculture, Assiut University, Assiut, Egypt. Intercropping of turnip and radish with faba bean resulted in significantly higher yields of both crops (turnip and radish) as compared with their sole cropping. All other characteristics (plant growth and yield components) of all the two crops which indicate yielding efficiency enhansment as a result of intercropping. Analysis of intercropping treatments revealed that faba bean intercropping with turnip increased the yield of turnip by (50.87- 51.13\%)when planting were done in sprinkle and by(18.18$19.35 \%$ ) when planting were done in hills as compared with sole crops in the first and second seasons respectively. However intercropping radish with faba bean resulted in the highest yield in radish by $(66.74-67.48 \%)$ when planting were done in sprinkle and by (75.27-81.55\%) when planting were done in hills as compared with sole crops in the first and second season respectively.Yield of faba bean increased when intercropped with radish by $(9.82-13.16 \%)$ rather than intercropping with turnip or sole cropping. Land equivalent ratio (LER) of faba bean-radish intercropping was, on average, 2.7 for both years. With regard to faba bean- turnip intercropping, (LER) was, on average, 2.6 for both years.
\end{abstract}

Keywords:Crop quality,main crop, secondary crop, sustainable agriculture,yield components.

\section{Introduction}

Increased agricultural production through intercropping with minimal cost is needed to feed increasing human population. In order to increase the yield in vegetable production, the yield obtained per unit area should be increased. Intercropping is the practice of growing two or more crops together so that they interact agronomically (Vandermeer, 1989) In general intercropping means growing at least two different crops at the same cultivation season and in the same area (Kizilsimsek and Erol,
2000). The increasing concern over agricultural sustainability favors the maintenance of intercropping systems due to its positive effect on soil conservation and improvement of soil fertility (Jarenyama et al., 2000). Additionally, more stable yields of intercropped systems use natural resources more effectively (Horwith, 1985). Intercropping with legumes makes effective use of land and other resources and results in reduced cost of production There are many studies on intercropping. But the information is very scanty on intercropping with 
faba bean in vegetable production. Faba bean was used as the main crop and radish and turnip were used as an intercrop for two years under field conditions. The reported work evaluates the efficiencies of faba bean, turnip and radish grown as sole crops and when radish and turnip intercropped with faba bean during 20142015 and 2015-2016 seasons. Intercropping involving legumes has been found to be most useful (Adeniyi, 2011) as it improves soil fertility and gives better yields and economic returns (Lithourgidis et al., 2011). In another study, it was determined that radish and turnip adversely affected plant growth and reduced yield in cabbage and increased yield in peas and faba beans (Sharma et al., 1988).

\section{Materials and Methods}

This study was carried out at the Experimental Farm of Faculty of Agriculture, Assiut University, Assiut, Egypt, during 2014-2015 and 2015-2016 winter seasons. Faba bean (Vicia faba L.) was used as the main crop. Radish (Raphanus sativus L.) and turnip (Brassica rapa var. rapa) were grown alone and also in combination as secondary crops with faba bean. The experiment was conducted using three replications as randomized complete-block design.

The experiment consisted of 27 plots in total ( 9 treatments and 3 replications) as follows:1) faba bean with radish (sprinkle), 2) faba bean with radish (in hills), 3) faba bean with turnip (sprinkle), 4) faba bean with turnip (in hills), 5) faba bean alone,6) radish alone(sprinkle),7) radish alone (in hills), 8) turnip alone (sprinkle), 9) turnip alone (in hills).
Planting was carried out in the second week of October in both years. Faba bean planting was done $30 \mathrm{~cm}$ apart on the northern side of the ridge, while radish and turnip planting were done either in sprinkle or in hills on both sides of row. Three ridges (70 $\mathrm{cm}$ apart and $3 \mathrm{~m}$ long) were included in each plot. Sprinkle plants were thinned after 15 days from sowing at $3 \mathrm{~cm}$ apart $(95$ plants $/ \mathrm{m}^{2}$ ). Plants that grown in hills were at $5 \mathrm{~cm}$ apart $\left(58\right.$ plants $\left./ \mathrm{m}^{2}\right)$. The plants were fertilized with $15-20$ $\mathrm{kg} /$ fed ammonium nitrate $(33.5 \% \mathrm{~N})$, $150 \mathrm{~kg} /$ fed calcium superphosphate $\left(\begin{array}{lllll}15.5 \% & \mathrm{P}_{2} \mathrm{O}_{5}\end{array}\right)$ and $50 \quad \mathrm{~kg} / \mathrm{fed}$ potassium sulfate $\left(48 \% \mathrm{~K}_{2} \mathrm{O}\right)$. Half of these fertilizers amount was added during soil preparation. Other agricultural practices of irrigation, pest control..., etc, were applied as recommended for faba bean production (Hassan, 1991).

Data collection and analysis: Data were recorded on the following traits for radish and turnip crops: plant height $(\mathrm{cm})$, number of leaves per plant, root diameter $(\mathrm{cm})$, dry matter of vegetative parts (\%), dry matter of roots (\%) and total crop yield (ton/feddan). For faba bean the follows traits were recorded: plant height $(\mathrm{cm})$, pod length $(\mathrm{cm})$, pod diameter $(\mathrm{cm})$, nummber of branches per plant, nummber of seeds per pod, total pulse crop yield (ton/ feddan). Data of each season were grouped in each season separately as affected with intercropping crop. The treatments were grouped for analysis of variance according to the target (Mohamed et al.,2007). The first ANOVA was for faba bean as follows:1) faba bean with radish 
(sprinkle), 2) faba bean with radish (in hills), 3) faba bean with turnip (sprinkle), 4) faba bean with turnip (in hills),5) faba bean alone.The second ANOVA was for radish as follows:1) faba bean with radish (sprinkle), 2) faba bean with radish (in hills), 3) radish alone (sprinkle), 4) radish alone (in hills). The third ANOVA was for turnip as follows:1) faba bean with turnip (sprinkle), 2) faba bean with turnip (in hills), 3) turnip alone (sprinkle), 4) turnip alone (in hills). They were subjected to analysis of variance according to Snedecor and Cochran (1980). Based on homogeniety of error variance, the two seasons combined data were used in combined analysis of variance. Means of the treatments were compared using the Least Significant Difference (LSD) test at 0.05 propability level.

\section{Intercropping parameters \\ Efficiency}

Land Equivalent Ratio (LER) was determined according to Willey (1979) where:

$\mathrm{LER}=$ (intercropping yield of main crop/ monocrop yield of main crop)+(intercropping yield of second crop/monocrop of a second crop).

\section{Results}

Influence of intercropping each of radish and turnip on growth and yield parameters of faba bean:

Data (in Table 1) showed that,intercropping radish that grown in hills with faba bean resulted to higher values in plant height, pod length, number of seeds in pod and number of branches per plant for faba bean plants, Yield of faba bean increased when intercropped with radish. However, the differences among intercropping treatments were found to be statistically significant for all the parameters (Table 1). The maximum yield was recorded when radish was planted in hills as intercrop with faba bean .

Influence of intercropping with faba bean on growth and yield parameters of radish:

Data (in Table 2) for Root diameter gave the highest value when radish was intercroped with faba bean in hills than either when radish intercropping with faba bean (sprinkle) or when radish crop grown as sole crop. On the other hand,nummber of leaves per plant and dry matter percentage for each of vegetative parts or root parts gave the highest value when radish crop was intercropped with faba bean.

Intercropping of radish with faba bean resulted in significantly higher yields of radish whether in hills or sprinkle as compared with their sole cropping. All other characteristics (plant growth and yield components) of radish which indicate yielding efficiency enhansment as a result of intercropping. In Table (2), analyses of intercropping treatments revealed that radish intercropping with faba bean resulted in the highest yield in radish by (66.74- 67.48\%) when planting were done in sprinkle and by (75.27-81.55\%) when planting were done in hills as compared with sole crops in the first and second season respectively.

Influence of intercropping with faba bean on growth and yield parameters of turnip:

Data of different growth and yield characteristics for turnip were 
subjected to statistical analysis, which indicated significant differences among the intercropping treatments for all the parameters (Table 3). The maximum plant height, number of leaves per plant, dry matter percentage of root parts and root diameter for turnip crop were the maximum when turnip intercropping with faba bean. Also, Intercropping of faba bean with turnip resulted in significantly higher yields of turnip as compared with their sole cropping. The maximum yield was recorded when turnip intercropping with faba bean (sprinkle). The treatment means revealed that faba bean intercropping with turnip increased the yield by (50.87$51.13 \%$ ) when planting were done in sprinkle and by (18.18-19.35\%) when planting were done in hills as compared with sole crops in the first and second seasons respectively. In Table 4, Land equivalent ratio (LER) of faba bean-radish intercropping was, on average,2.7 for both years. With regard to faba beanturnip intercropping, (LER) was, on average, 2.6 for both years.

\section{Discusion}

Intercropping has been identified as a promising system that makes effective use of land and other resources (Remison, 1982 and Mohmed et al.,2007) like water and soil nutrients and results in reduced cost of production (Bijay et al., 1978). It has been demonstrated that the advantages of intercropping in vegetables could lead to better land use efficiency (Mohamed et al.,2007) as an important component of sustainable farming (Guvene and Yildrin, 1999). Intercropping can significantly enhance crop productivity compared to the growth of sole crops (Midmore, 1993).

Advantages of intercropping with legumes have been demonstrated in numerous studies; tomato or okra with cowpea (Mohamed et al., 2007 and Olasantan, 1991), cucumber with cowpea (Susan and Mini, 2005), maize with cowpea (Akande et al., 2006), cassava with cowpea (Mohammed et al., 2006). These studies have indicated that intercropping was more productive than sole cropping because of the completation effect of intercrops. Leguminous plants currently present apromising opportunity in sustainable maintenance of soil fertility. Intercropping involving legumes has been found to be most useful (Adeniyi, 2011) as it improves soil fertility and gives better yields and economic returns (Lithourgidis et al., 2011). Common beans are poor fixers (less than $56 \mathrm{~kg}$ ha-1 per growing season) and fix less than their nitrogen needs. Other grain legumes, such as peas, peanuts, cowpeas, soybeans and faba beans are good nitrogen fixers and can fix all of their nitrogen needs other than that absorbed from the soil. These legumes may fix up to $280 \mathrm{~kg}$ $\mathrm{N}$ ha-1 and are not usually fertilized with $\mathrm{N}$ (Lindemann and Glover, 2003). Almost all of the fixed nitrogen goes directly into the plant and little leaks into the soil for neighboring non-legume plants. Eventually, nitrogen returns to the soil for following crops when vegetation (roots, leaves, fruits) of the legume dies and decomposes (Lindemann and Glover, 2003; Rahman et al., 2009). Since excessive use of inorganic fertilizers contribute to environmental damage 
such as nitrate pollution; yield is increased because growth resources such as light, water and nutrients are more efficiently absorbed and converted to crop biomass by the intercropping. The "LER" of the faba bean-radish intercropping and faba bean-turnip intercropping were greater than 1.0 indicating a higher combined yield was produced than for mono-cropped faba bean. However, net benefit to the grower was higher in case of faba bean intercropping with radish, followed by faba bean intercropping with turnip.

Table 1. Effects of intercropping of some characters in faba bean main crop grown in 2014-2015 and 2015-2016 winter seasons ${ }^{(1)}$.

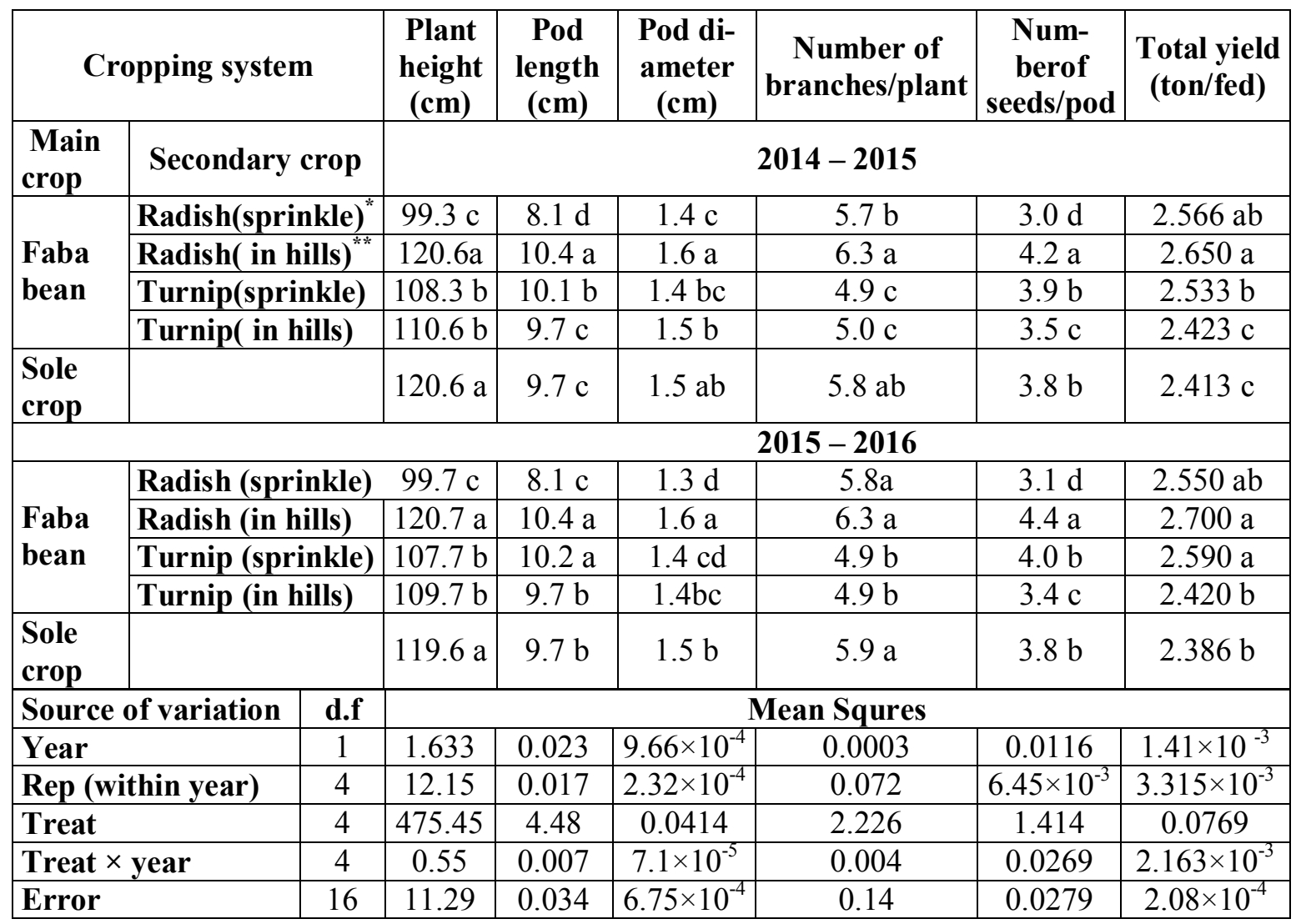

(1) means within column followed by the same letter(s) are not significantly different at 0.05 level of probability.

* Sprinkle plants were thinned after 15 days from sowing at $3 \mathrm{~cm}$ apart ( 95 plants $/ \mathrm{m} \mathrm{2}$ ).

${ }^{* *}$ Plants that grown in hills were at $5 \mathrm{~cm}$ apart ( 58 plants $/ \mathrm{m} \mathrm{2}$ ). 
Table 2. Effects of intercropping onf some characters of radish secondary crop in 2014-2015 and 2015-2016 winter seasons ${ }^{(1)}$

\begin{tabular}{|c|c|c|c|c|c|c|c|}
\hline \multicolumn{2}{|c|}{ Cropping system } & $\begin{array}{c}\text { Plant } \\
\text { height } \\
\text { (cm) }\end{array}$ & $\begin{array}{l}\text { Number of } \\
\text { leaves/plant }\end{array}$ & $\begin{array}{c}\text { Root } \\
\text { diameter } \\
(\mathrm{cm})\end{array}$ & $\begin{array}{c}\text { Dry } \\
\text { matter of } \\
\text { vegetative } \\
\text { parts }(\%)\end{array}$ & $\begin{array}{c}\text { Dry } \\
\text { matter } \\
\text { of root } \\
(\%)\end{array}$ & $\begin{array}{c}\text { Total } \\
\text { yield } \\
\text { (ton/fed) }\end{array}$ \\
\hline Secondary crop & $\begin{array}{l}\text { Main } \\
\text { crop }\end{array}$ & \multicolumn{6}{|c|}{ 2014- 2015} \\
\hline Radish(sprinkle) & \multirow{4}{*}{$\begin{array}{l}\text { Faba } \\
\text { bean }\end{array}$} & $88.3 \mathrm{a}$ & $7.0 \mathrm{a}$ & $5.3 \mathrm{~b}$ & $40.40 \mathrm{a}$ & $53.57 \mathrm{a}$ & $6.870 \mathrm{a}$ \\
\hline Radish (in hills) & & $86.3 \mathrm{a}$ & $7.3 \mathrm{a}$ & $5.7 \mathrm{a}$ & $41.37 \mathrm{a}$ & $49.23 \mathrm{~b}$ & $6.450 \mathrm{~b}$ \\
\hline $\begin{array}{l}\text { Sole crop } \\
\text { (sprinkle) }\end{array}$ & & $60.3 \mathrm{~b}$ & $5.3 \mathrm{c}$ & $4.8 \mathrm{~d}$ & $12.23 \mathrm{c}$ & $34.20 \mathrm{~d}$ & $4.120 \mathrm{c}$ \\
\hline $\begin{array}{l}\text { Sole crop } \\
\text { (in hills) }\end{array}$ & & $65.1 \mathrm{~b}$ & $5.7 \mathrm{bc}$ & $5.0 \mathrm{c}$ & $23.3 \mathrm{~b}$ & $37.67 \mathrm{c}$ & $3.680 \mathrm{~d}$ \\
\hline & & \multicolumn{6}{|c|}{ 2015- 2016} \\
\hline Radish(sprinkle) & \multirow{4}{*}{$\begin{array}{l}\text { Faba } \\
\text { bean }\end{array}$} & $87.5 \mathrm{a}$ & $7.0 \mathrm{a}$ & $5.3 \mathrm{~b}$ & $40.18 \mathrm{a}$ & $53.57 \mathrm{a}$ & $6.830 \mathrm{a}$ \\
\hline Radish( in hills) & & $86.8 \mathrm{a}$ & $7.6 \mathrm{a}$ & $5.7 \mathrm{a}$ & $42.49 \mathrm{a}$ & $49.33 \mathrm{~b}$ & $6.347 \mathrm{~b}$ \\
\hline $\begin{array}{l}\text { Sole crop } \\
\text { (sprinkle) }\end{array}$ & & $60.8 b$ & $5.4 \mathrm{~b}$ & $4.8 \mathrm{~d}$ & $11.83 \mathrm{c}$ & $33.83 \mathrm{c}$ & $4.078 \mathrm{c}$ \\
\hline $\begin{array}{l}\text { Sole crop } \\
\text { (in hills) }\end{array}$ & & $67.0 \mathrm{~b}$ & $5.9 \mathrm{~b}$ & $4.9 \mathrm{c}$ & $20.40 \mathrm{~b}$ & $36.30 \mathrm{c}$ & $3.496 \mathrm{~d}$ \\
\hline $\begin{array}{l}\text { Source of varia- } \\
\text { tion }\end{array}$ & d.f & \multicolumn{6}{|c|}{ Mean Squres } \\
\hline Year & 1 & 1.606 & 0.109 & $1.616 \times 10^{-3}$ & 2.169 & 1.001 & 0.052 \\
\hline $\begin{array}{l}\text { Rep (within } \\
\text { year) }\end{array}$ & 4 & 15.04 & 0.088 & $3.75 \times 10^{-3}$ & 0.889 & 0.302 & $2.144 \times 10^{-3}$ \\
\hline Treat & 3 & 1177.9 & 5.74 & 0.959 & 1267.45 & 534.306 & 15.936 \\
\hline Treat $\times$ year & 3 & 1.868 & 0.018 & $3.036 \times 10^{-3}$ & 4.235 & 0.667 & $7.019 \times 10^{-3}$ \\
\hline Error & 12 & 19.43 & 0.24 & 0.0127 & 7.648 & 3.436 & 0.013 \\
\hline
\end{tabular}

(1) means within column followed by the same letter(s) are not significantly different at 0.05 level of probability. 
Table 3. Effects of intercropping of some characters in turnip secondary crop in 2014-2015 and 2015-2016 winter seasons

\begin{tabular}{|c|c|c|c|c|c|c|c|}
\hline \multicolumn{2}{|c|}{ Cropping system } & $\begin{array}{c}\text { Plant } \\
\text { height } \\
(\mathrm{cm})\end{array}$ & $\begin{array}{l}\text { Number } \\
\text { of leaves }\end{array}$ & $\begin{array}{c}\text { Root } \\
\text { diame- } \\
\text { ter }(\mathbf{c m})\end{array}$ & $\begin{array}{c}\text { Dry } \\
\text { matter of } \\
\text { vegetative } \\
\text { parts }(\%)\end{array}$ & $\begin{array}{c}\text { Dry } \\
\text { matter } \\
\text { of root } \\
(\%)\end{array}$ & $\begin{array}{l}\text { Total yield } \\
\text { (ton/fed) }\end{array}$ \\
\hline Seconday crop & $\begin{array}{l}\text { Main } \\
\text { crop }\end{array}$ & \multicolumn{6}{|c|}{ 2014-2015 } \\
\hline $\begin{array}{l}\text { Turnip } \\
\text { (sprinkle) }\end{array}$ & \multirow{4}{*}{$\begin{array}{l}\text { Faba } \\
\text { bean }\end{array}$} & $87.2 \mathrm{a}$ & $6.4 \mathrm{a}$ & $7.1 \mathrm{a}$ & $22.40 \mathrm{c}$ & $52.80 \mathrm{a}$ & $8.283 \mathrm{a}$ \\
\hline $\begin{array}{l}\text { Turnip } \\
\text { ( in hills) }\end{array}$ & & $91.8 \mathrm{a}$ & $6.7 \mathrm{a}$ & $7.2 \mathrm{a}$ & $36.50 \mathrm{a}$ & $55.90 \mathrm{a}$ & $6.266 \mathrm{~b}$ \\
\hline Sole crop (sprinkle) & & $62.7 \mathrm{~b}$ & $6.2 \mathrm{a}$ & $6.3 \mathrm{~b}$ & $27.76 \mathrm{~b}$ & $46.93 \mathrm{~b}$ & $5.490 \mathrm{c}$ \\
\hline $\begin{array}{l}\text { Sole crop } \\
\text { (in hills) }\end{array}$ & & $57.3 \mathrm{~b}$ & $5.4 \mathrm{~b}$ & $5.6 \mathrm{c}$ & $14.00 \mathrm{~d}$ & $46.56 \mathrm{~b}$ & $5.250 \mathrm{c}$ \\
\hline & & \multicolumn{6}{|c|}{$2015-2016$} \\
\hline $\begin{array}{l}\text { Turnip } \\
\text { (sprinkle) }\end{array}$ & \multirow{4}{*}{$\begin{array}{l}\text { Faba } \\
\text { bean }\end{array}$} & $86.0 \mathrm{a}$ & $6.5 \mathrm{a}$ & $6.8 \mathrm{ab}$ & $22.10 \mathrm{c}$ & $52.69 \mathrm{a}$ & $8.290 \mathrm{a}$ \\
\hline $\begin{array}{l}\text { Turnip } \\
\text { ( in hills) }\end{array}$ & & $91.2 \mathrm{a}$ & $6.7 \mathrm{a}$ & $7.0 \mathrm{a}$ & $35.68 \mathrm{a}$ & $55.30 \mathrm{a}$ & $6.143 \mathrm{~b}$ \\
\hline Sole crop (sprinkle) & & $62.7 \mathrm{~b}$ & $6.1 \mathrm{~b}$ & $6.3 \mathrm{~b}$ & $27.52 \mathrm{~b}$ & $46.17 \mathrm{~b}$ & $5.485 \mathrm{c}$ \\
\hline $\begin{array}{l}\text { Sole crop } \\
\text { (in hills) }\end{array}$ & & $56.3 \mathrm{~b}$ & $5.3 \mathrm{c}$ & $5.4 \mathrm{c}$ & $12.51 \mathrm{~d}$ & $45.27 \mathrm{~b}$ & $5.198 \mathrm{c}$ \\
\hline Source of variation & d.f & \multicolumn{6}{|c|}{ Mean Squres } \\
\hline Year & 1 & 3.003 & $1.66 \times 10^{-3}$ & 0.177 & 3.048 & 2.87 & 0.011 \\
\hline Rep (within year) & 4 & 7.426 & 0.929 & 0.018 & 0.858 & 7.456 & 0.019 \\
\hline Treat & 3 & 1774.58 & 2.047 & 3.141 & 550.71 & 134.48 & 11.55 \\
\hline Treat $\times$ year & 3 & 0.402 & 0.0117 & 0.025 & 0.498 & 0.363 & $6.17 \times 10^{-3}$ \\
\hline Error & 12 & 13.92 & 0.0716 & 0.0475 & 4.726 & 7.129 & 0.03 \\
\hline
\end{tabular}

${ }^{(1)}$ means within column followed by the same letter(s) are not significantly different at 0.05 level of probability by using the Duncan Multiple Range Test 
Table 4. Average"Land Equivalent Ratio" values for faba bean-radish and faba bean-turnip intercropping when radish and turnip planted simultaneously with fabba bean.

\begin{tabular}{|l|c|c|c|c|c|c|}
\hline \multirow{2}{*}{ Treatments } & \multicolumn{6}{|c|}{ Land equivalent ratio* } \\
\cline { 2 - 7 } & \multicolumn{5}{|c|}{ First season } & Faba bean-Radish \\
\cline { 2 - 7 } & $\begin{array}{l}\text { Faba } \\
\text { bean }\end{array}$ & Radish & Sum & $\begin{array}{c}\text { Faba } \\
\text { bean }\end{array}$ & Radish & Sum \\
\hline $\begin{array}{l}\text { Faba bean with } \\
\text { radish(in sprinkle) }\end{array}$ & 1.063 & 1.667 & 2.730 & 1.068 & 1.674 & 2.743 \\
\hline $\begin{array}{l}\text { Faba bean with } \\
\text { radish (in hills) }\end{array}$ & 1.098 & 1.752 & 2.850 & 1.131 & 1.815 & 2.947 \\
\hline & $\begin{array}{l}\text { Faba } \\
\text { bean }\end{array}$ & Turnip & Sum & $\begin{array}{c}\text { Faba } \\
\text { bean }\end{array}$ & Turnip & Sum \\
\hline $\begin{array}{l}\text { Faba bean with } \\
\text { turnip (in sprinkle) }\end{array}$ & 1.049 & 1.508 & 2.558 & 1.014 & 1.511 & 2.596 \\
\hline $\begin{array}{l}\text { Faba bean with } \\
\text { turnip(in hills) }\end{array}$ & 1.004 & 1.193 & 2.197 & 1.085 & 1.181 & 2.196 \\
\hline
\end{tabular}

$*=$ ( intercropping yield of main crop/ monocrop yield of main crop) $+($ intercropping yield of second crop/monocrop of a second crop).

Table 5. Productivity of each of faba bean, radish and turnip as sole crops and when radish and turnip(secondary crop) intercropped with faba bean(main crop), and the income in pounds in each case. ${ }^{(1)}$

\begin{tabular}{|l|c|c|c|c|c|c|}
\hline & \multirow{2}{*}{$\begin{array}{c}\text { Treatments } \\
\text { yield(ton/fed) }\end{array}$} & $\begin{array}{c}\text { Total } \\
\text { yield(ton/fed) } \\
\text { for secondary } \\
\text { for main crop }\end{array}$ & $\begin{array}{c}\text { Price in pound } \\
\text { crop }\end{array}$ & $\begin{array}{c}\text { Tor ton } \\
\text { crotal price } \\
\text { crop }\end{array}$ & $\begin{array}{c}\text { Main } \\
\text { (pound) }\end{array}$ \\
\hline Faba bean(sole) & 2.143 & - & 10000 & - & 21430 & - \\
\hline $\begin{array}{l}\text { Faba bean with } \\
\text { radish(sprinkle) }\end{array}$ & 2.566 & 6.870 & 10000 & 8000 & 25660 & 54960 \\
\hline $\begin{array}{l}\text { Faba bean with } \\
\text { radish(hills) }\end{array}$ & 2.650 & 6.450 & 10000 & 8000 & 26500 & 51600 \\
\hline Radish(sole)(sprinkle) & - & 4.120 & - & 8000 & - & 32960 \\
\hline Radish(sole)(hills) & - & 3.680 & - & 8000 & - & 29440 \\
\hline $\begin{array}{l}\text { Faba bean with } \\
\text { turnip(sprinkle) }\end{array}$ & 2.533 & 8.283 & 10000 & 2000 & 25330 & 16566 \\
\hline $\begin{array}{l}\text { Faba bean with } \\
\text { turnip(hills) }\end{array}$ & 2.423 & 6.266 & 10000 & 2000 & & 12532 \\
\hline Turnip(sole)(sprinkle) & - & 5.490 & - & 2000 & - & 10980 \\
\hline Turnip(sole)(hills) & - & 5.250 & - & 2000 & - & 10500 \\
\hline
\end{tabular}

${ }^{(1)}$ Total price in pound was calculated according to the price of vegetable marketable 


\section{Literature Cited}

Adeniyi, O.R. (2011). Economic aspects of intercropping systems of vegetables (okra, tomato and cowpea). Afr. J. Plant Sci. 5:648-655.

Akande, M. O.; Oluwatoyinbo, F. I.; Kayode, C. O. and Olowokere, F. A. (2006). Response of maize (Zea mays) and okra (Abelmoschus esculentus) intercrop relayed with cowpea (Vigna unguiculata) to different levels of cow dung amended phosphate rock. World Journal of Agriculture Sciences. 2(1): 119122.

Bijay, S., D.S. Rana and G.S. Sekhon. (1978). Some measures of reducing leaching loss of nitrate beyond rooting zone. Plant Soil 49:633639.

Hassan, A. A. (1991). Production of vegetable crops.1st ed., Published by Arab House for Publishing and Distribution, Cairo, Egypt. (in Arabic).

Horwith B (1985). A role for intercropping in modern agriculture. BioScience, 35: 5.

Guvene, I. and Yildrin, E. (1999). Multiple cropping systems in vegetable production. In Proceeding of the Organic Agriculture Symposium, 21-23 June, Izmin, Turkey. Pp288-296.

Jarenyama P, Hesterman OB, Waddington SR, Harwood RR (2000). Relay-intercropping of sunnhemp and cowpea into a smallholder maize system in Zimbabwe. Agron. J., 92: 239-244.

Kizilsimsek M, Erol A (2000). Land Equivalent Ratio, Inter Species Competition and
Nutrient Supplementation Index in Intercropping of Forage Crops. J. Sci. Eng., 3(1), 14-22.

Lindemann, W.C. and C.R. Glover. (2003). Nitrogen fixation by legumes. Guide A-129, New Mexico State University, New Mexico, USA.

Lithourgidis, A.S., C.A. Dordas, C.A. Damalas and D.N. Vlachostergios. (2011). Annual intercrops: an alternative pathway for sustainable agriculture. Aust. J. Crop Sci. 5:396-410.

Midmore, D. J. (1993). Agronomic modification of resources use and intercrop productivity. Field Crops Research. 34: 357-380.

Mohammed, M. A.; Variyapuri, K.; Alagesan, A.; Somasundaram, E.; Sathyamoorths, K. and Pazhanivelan, S. (2006). Effect of intercropping and organic manures on yield and biological efficiency of cassava intercropping system (Manihot esculenta, crantz). Research Journal of Agriculture and Biological Sciences. 2(5): 201-208

Mohamed, F.M ; M.H. Dokashi and M.A. Mousa. (2007). Yield of crops in within-row intercropped okra-cowpea or okra-cucumber. International Journal of vegetable science, Vol.13(2):33-48.

Olasantan, F. O. (1991). Response of tomato and okra to nitrogen fertilizer in sole

cropping and intercropping with cowpea. Horticultural Science 66: 191-199.

Rahman, M.M., T. Amano and T. Shiraiwa. (2009). Nitrogen use efficiency and recovery from $\mathrm{N}$ fertilizer under rice based cropping 
systems. Aust. J. Crop Sci. 3:336351.

Remison, S.U. (1982). Interaction between maize and cowpea at various frequencies. J.

Agric. Sci. 94:617-621.

Sharma RP, Patil RR, Arora PN (1988). Spatial arrangement and methods of planting in cabbage (Brassica oleracea convar. capitata var. capitata) intercropping. Indian J. Agric. Sci., 58(9): 673-677.

Snedecor, C.W. and W.G. Cochran. (1980). Statistical methods. 6th ed. Iowa Univ. Press, Ames, Iowa, U.S.A.
Susan, A. J. and Mini, C. (2005). Biological efficiency of intercropping in okra (Abelmoschus esculentus, L. Moench). Journal of Tropical Agriculture. 43(1-2): 33-36.

Vandermeer J. (1989). The ecology of intercropping. Cambridge Universty Press, Cambridge, UK, p. 237.

Willey, R.W. (1979). Intercropping- its importance and research needs,part 1.competition and yield advantages. Field crop Res. 32(1):1-10. 
تأثير تحميل الفجل واللفت مع الفول على النمو والمحصول تحت ظروف اسيوط

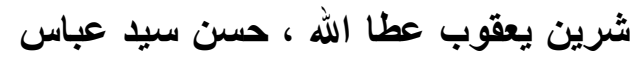
قسم الخضر - كلية الزر اعة- جامعة اسيوط

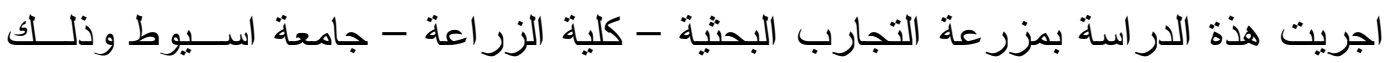

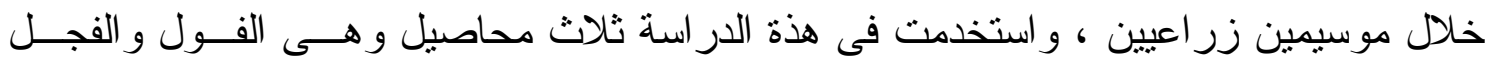

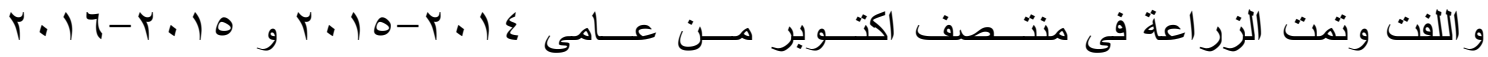

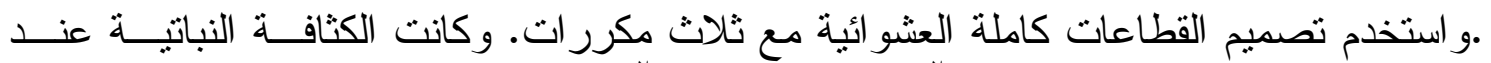

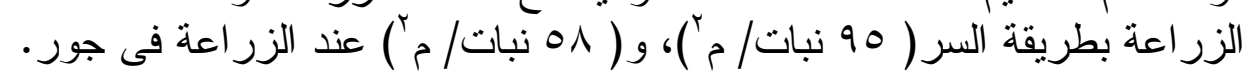

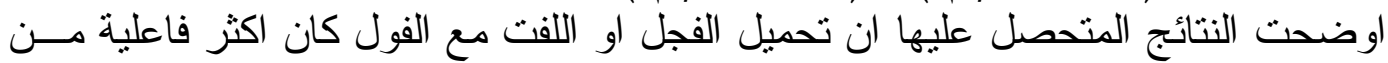

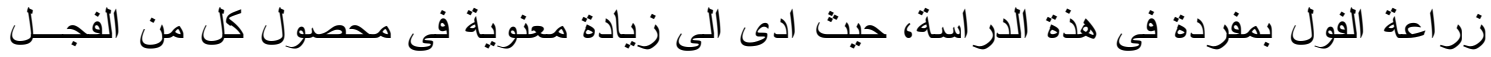

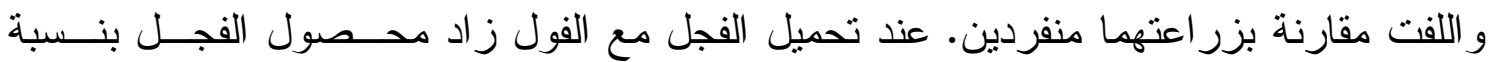

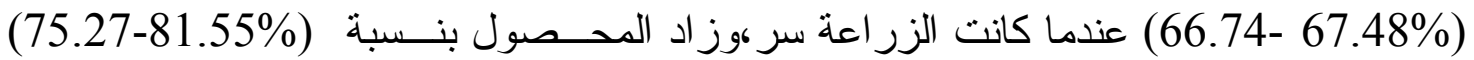

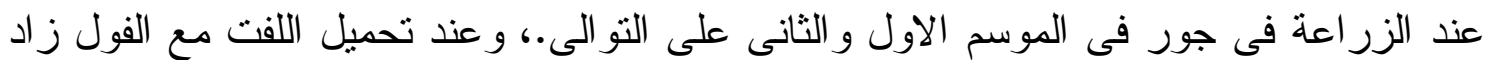

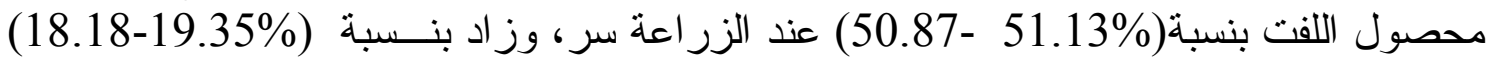

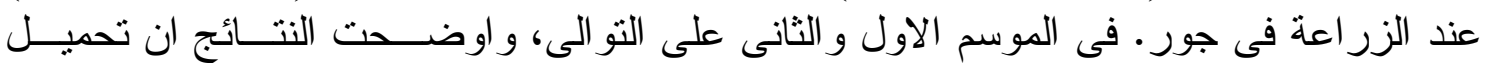

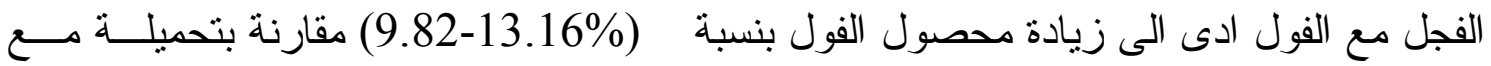

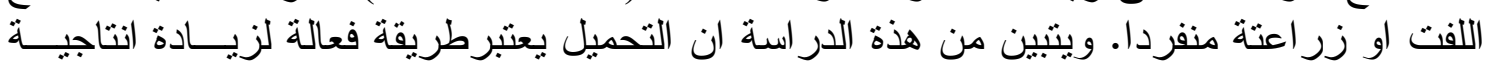

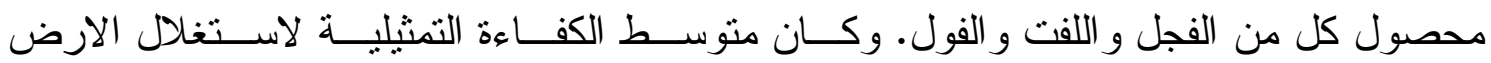

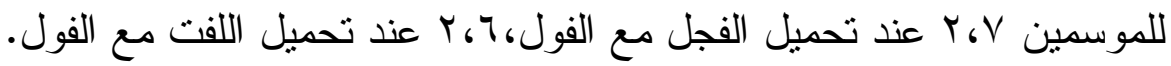

